\title{
Expansion of the geographical distribution of Trachycephalus typhonius (Linnaeus, 1758) (Anura: Hylidae): First record for the state of Rio Grande do Sul, Brazil
}

\author{
Marlon da Luz Soares ${ }^{1 *}$, Samanta Iop ${ }^{2}$ and Tiago Gomes dos Santos ${ }^{3}$ \\ 1 Universidade Regional Integrada do Alto Uruguai e das Missões (URI), Curso de Ciências Biológicas. Rua Universidade das Missões, $\mathrm{n}$ ำ 464. CEP \\ 98.802 - 470. Santo Ângelo, RS, Brasil. \\ 2 Universidade Federal de Santa Maria, Centro de Ciências Naturais e Exatas, Departamento de Biologia, Programa de Pós-graduação em \\ Biodiversidade Animal. Av. Roraima s/ n. CEP 97105-900. Santa Maria, RS, Brasil. \\ 3 Universidade Federal do Pampa (Unipampa). Av. Antônio Trilha, no 1847. CEP 97300-000. São Gabriel, RS, Brasil. \\ * Corresponding author. E-mail: marlo.bio@hotmail.com
}

\begin{abstract}
We report the first record of Trachycephalus typhonius for the state of Rio Grande do Sul, Brazil, based on individuals found in the municipalities of Roque Gonzales and Salvador das Missões. The original vegetation of these municipalities is characterized as Mesophytic Semideciduous Forest (Atlantic Domain), currently replaced by agricultural activities and urbanization. This record expands the geographical distribution area of this species by approximately $270 \mathrm{~km}$ from the nearest known locality, Iguazú, Misiones province, Argentina.
\end{abstract}

The genus Trachycephalus Tschudi, 1838 consists of 12 species belonging to the family Hylidae (Frost 2011), and has only one morphological synapomorphy, the presence of paired lateral vocal sacs, which protrude posteriorly to the angles of the jaws when inflated (Faivovich et al. 2005).

Trachycephalus typhonius (Linnaeus 1758) (Figure 1) was previously recognized as Trachycephalus venulosus (Laurenti 1768). However, the complex confusion on the identity of Rana typhonia was recently solved by Lavilla et al. (2010), which considered this species as an older synonym of Rana venulosa. Trachycephalus typhonius has wide geographical distribution, including Central America (southern Mexico) and South America (La Marca et al. 2010). In the latter, this species occurs throughout the Amazon basin to northern Argentina, and in Brazil it is recorded from the Amazon to Paraná (Frost 2011).

In February 2011, a female Trachycephalus typhonius was collected in a swamp environment in the municipality of Roque Gonzales (2807'53" S, 5501'53" W; $157 \mathrm{~m}$ elevation), and another specimen was recorded (identified and released) inside a human dwelling in the municipality

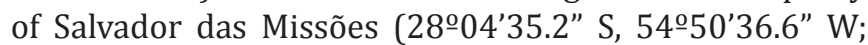
$209 \mathrm{~m}$ elevation), both located in the northwest of Rio Grande do Sul (SISBIO/RAN \#29509-1). The predominant vegetation of these areas is characterized as Mesophytic Semideciduous Forest of Atlantic Domain (Oliveira-Filho pers. com.), in transition area with the natural grasslands of the Pampa biome (IBGE, 2004). Nowadays, the natural vegetation has been widely replaced by agricultural activities and urbanization. The climate is characterized as humid subtropical with dry summers (ST UM v), according to the classification of Maluf (2000). The specimen collected was deposited in the Zoological Collection of the Universidade Federal de Santa Maria (ZUFSM 4415). Three additional specimens of T. typhonius (two males and one female) were found deposited in the Collection of the Museu de Ciências Naturais da Fundação Zoobotânica do
Rio Grande do Sul (MCN 10326-28), and were collected in 1979 at the campus of Pontifícia Universidade Católica do Rio Grande do Sul. In spite of these three specimens also presenting morphological features typical of T. typhonius, we have doubts on the reliability of data collection and prefer not to consider them as valid records of occurrence.

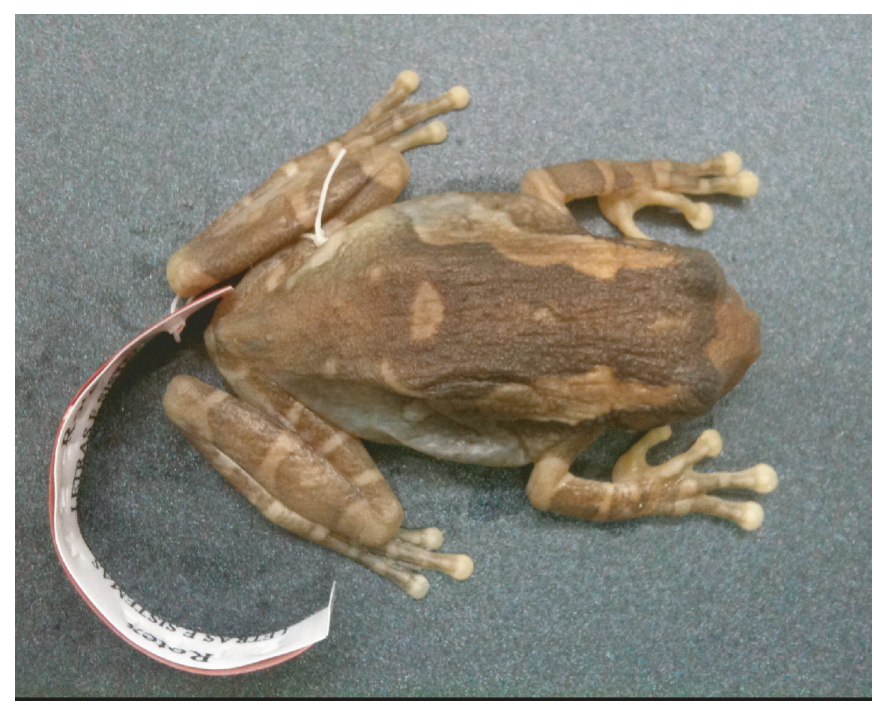

FIGURE 1. Female Trachycephalus typhonius of Roque Gonzales (ZUFSM 4415), Rio Grande do Sul state, Brazil. Photo by Vinícius Matheus Caldart.

These new localities constitute the first record of T. typhonius for the state of Rio Grande do Sul, Brazil, extending the geographical distribution area of this species by approximately $270 \mathrm{~km}$ from the nearest known locality, Iguazú, Misiones province, Argentina (Kwet and Solé 2008) (Figure 2).

In the state of Rio Grande do Sul two other species of Trachycephalus, T. mesophaeus (Hensel 1867) and T. dibernardoi (Kwet and Solé 2008), are also recorded. Trachycephalus typhonius presents remarkable polymorphism, ranging from broad dark longitudinal 
blotch to transversally divided or uniform/spotted patterns (see color patterns in Cei 1980). Trachycephalus mesophaeus presents as the main morphological differences from T. typhonius the absence of cross-bars on limbs, the greenish gray to dark brown colors, still having some shades of yellow with bright dorsolateral bands varying in width, and brightness and shape of the dark edges (Lutz 1973). Trachycephalus dibernardoi presents a greenish coloration with a remarkable distinct ocellus pattern, absent in T. typhonius (Kwet and Solé 2008). The authors also emphasized that T. dibernardoi differs from T. venulosus, the latter species presenting highly glandular dorsal and ventral skin including a well-developed parotoid in the head and neck region. In addition, the distribution of T. typhonius is related to Seasonal Forests of Atlantic Domain, Cerrado Savannah and Amazonian Forest, while T. mesophaeus occurs in the Atlantic Rain Forest, and T. dibernardoi is associated with the Araucaria Forest (Kwet and Solé 2008, Lavilla et al. 2010, Frost 2011). The occurrence of T. typhonius in Rio Grande do Sul was expected since it is a widespread species that can be found in a diverse number of habitat types from natural savannahs and forests to disturbed habitats, such as plantations and human dwellings (La Marca et al. 2010).

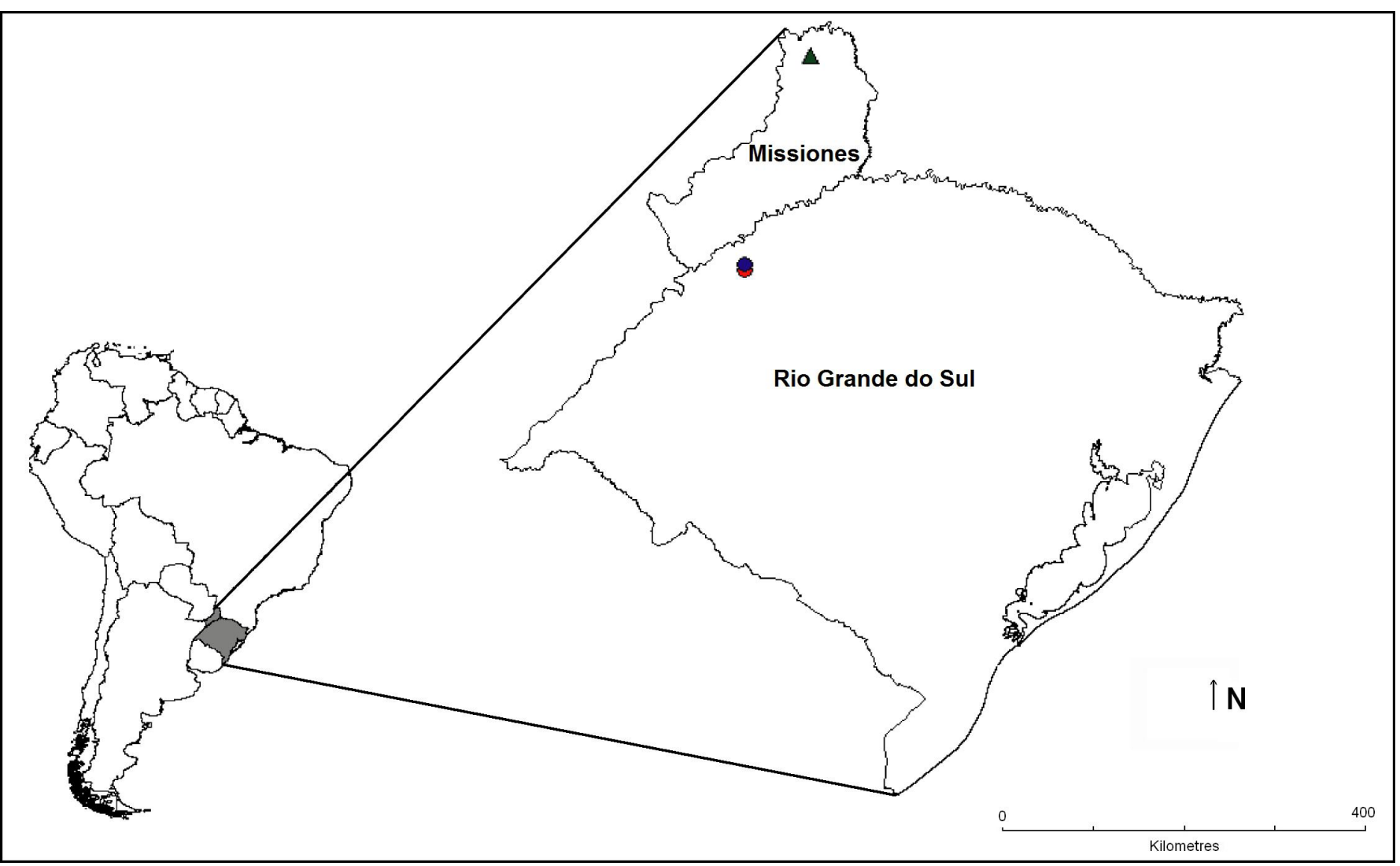

FIGURE 2. New records of Trachycephalus typhonius from the municipalities of Roque Gonzales (blue circle), and Salvador das Missões (red circle), Rio Grande do Sul state, Brazil. The green triangle indicates the nearest known locality: Iguazú, Misiones province, Argentina.

\section{LITERATURE Cited}

Cei, J.M. 1980. Amphibians of Argentina. Italian Journal of Zoology, Monografia 2: 1-609.

Faivovich, J., C.F.B. Haddad, P.C.A. Garcia, D.R. Frost, J.A. Campbell and W.C. Wheeler. 2005. Systematic review of the frog family Hylidae, with special reference to Hylinae: phylogenetic analysis and taxonomic revision. Bulletin of the American Museum of Natural History 294: $1-240$.

Frost, D.R. 2011. Amphibian Species of the World: an Online Reference. Version 5.4. Electronic Database accessible at http://research.amnh. org/herpetology/amphibia/. Captured on 26 April 2011.

IBGE 2004. Map of Biomes of Brazil. Scale 1:5.000.000. Rio de Janeiro. Electronic Database accessible at: ftp://ftp.ibge.gov.br/ Cartas_e_Mapas/Mapas_Murais/. Captured on 06 March 2011.

Kwet, A. and M. Solé. 2008. A new species of Trachycephalus (Anura: Hylidae) from the Atlantic Rain Forest in southern Brazil. Zootaxa 1947: 53-67.

La Marca, E., C. Azevedo-Ramos, N. Scott, L. Aquino, D. Silvano, L.A. Coloma, S. Ron, J. Faivovich, G. Santos-Barrera, F. Solís, R. Ibáñez, F. Bolaños, L.D. Wilson and J. Hardy. 2010. Trachycephalus venulosus In IUCN 2010. IUCN Red List of Threatened Species. Version 2010.1. Electronic Database accessible at www.iucnredlist.org. Captured on 02 May 2011.
Lavilla, E.O., J.A. Langone, J.M. Padial and R.O. De Sá. 2010. The identity of the crackling, luminescent frog of Suriname (Rana typhonia Linnaeus, 1758) (Amphibia, Anura). Zootaxa 2671: 17-30.

Lutz, B. 1973. Brazilian species of Hyla. Austin: University of Texas Press. $265 \mathrm{p}$.

Maluf, J.R.T. 2000. A new climatic classification for the state of Rio Grande do Sul, Brazil. Revista Brasileira de Agrometeorologia 8(1): 141-150.

RECEIVED: July 2011

ACCEPTED: July 2012

Published ONLINE: August 2012

EDITORIAL RESPONSIBILITY: Mara Cíntia Kiefer 